\title{
URINARY CATECHOL AMINE LEVELS, GASTRIC SECRETION AND SPECIFIC PSYCHOLOGICAL FACTORS IN ULCER AND NON-ULCER PATIENTS*
}

\author{
Sanford I Cohen, M.D,$\dagger$ Albert J Silverman, M.D. $\dagger$ \\ William Waddell, M D $\ddagger$ George D. Zuidema, M D. +
}

(Recelved $18 J_{\text {uly 1960) }}$

\section{INTRODUCTION}

A CONSIDERABLE body of information has been gathered which has suggested that the pathophysiology of duodenal ulcers is influenced by psychological factors operating through the effects of the central and autonomic nervous system on gastric physiology. However, untıl recent years, there has been a paucity of experimental studies in which multıple interactıng predisposing and precipitatıng elements could be demonstrated. Many of the earlier studies were limited to the investigation of the specific physiological precipitants of duodenal ulcerations or the specific psychodynamic or personality correlates found in patients with peptic ulcers. (IVY et al 1950, Grossman 1951, Hunt and Kay 1954, AleXANDER et al. 1934, KapP et al. 1947, SZASZ et al 1947, RUESCH 1948, GILdEA 1949, STREITFELd 1954; MINSKI and Desai 1955, Weisman 1956)

The highlighting of a limited number of specific factors in each individual study led to the amassing of a large body of research data which has remained relatively unintegrated from an experımental point of view Hence, there has been scant data to support the empirically developed concepts that peptic ulcer was a "psychosomatic" dysfunction. Because of this there has been no general agreement among the clinical specialties concernıng the "proper" management program of patients with ulcers which would incorporate principles based on a consideration of the multiple determinants of the cause and the course of the disease

The work which will be reported in this paper represents the convergence of three investigations which originally were unrelated However, the data from the studies suggested an experimental design which would allow for the testing of an hypothesis of the interaction of psychological, gastric, physiological and neuro-humoral factors in the development of duodenal ulcers.

\section{BACKGROUND STUDIES}

The investigation which will be described in this publication was based on the findings of three separate studies

* The investigations described in this paper were supported by grants from (1) The United States Public Health Service (A-1836 (R1)), (2) National Institute of Mental Health, United States Public Health Service grant M 2061 and contracts between (1) Duke University and the United States Air Force Office of Scientific Research (AF-49(638)-354), (2) Massachusetts Generdl Hospital and the Unıted States Air Force (49(638)98)

$\dagger$ Co-Heads of the Division of Psychophysiological Research, Department of Psychıatry, Duke University Medical Center

$\ddagger$ Members of the Department of Surgery, Harvard Medical School at the time of the preparation of this paper Dr Zuidem is at present at the University of Michigan Medical School 
(A) The work of Weiner, Thaler, Reiser and Mirsky (1957) and Mirsky (1958) was concerned with a propter hoc psychologic evaluation of a group of healthy subjects together with the assessment of their serum pepsinogen levels These subjects were a group preparing to enter an environmental situation which might have noxious or traumatic meanıng to some of them (induction into the armed service ) The study was designed to evaluate the predictive value of biochemical, psychological and sociological factors which had been assumed to be related to gastrointestınal activity In this study, the concentration of serum pepsinogen was used as an index of gastric secretion "Hypo" and "hyper" secretors were studied in terms of their style of inter-personal interaction that could be inferred from psychoanalytically oriented interviews and derived from projective tests and other psychological techniques

All of the subjects who had or who developed evidence of duodenal ulcer were found among the subjects with high pepsinogen values Independent evaluation of the psychological data revealed that the subjects who developed peptic ulcer had displayed evidence of major unresolved and persistent conflicts with their need for dependent oral gratıfication A psychodynamic constellation was formulated on the basis of several of the psychological tests (Blacky Test, Saslow Questionnaire, Rorschach, etc ) which correlated well with the hyper- and the hypo-pepsinogen secretor ratıngs, as well as, being able to predict the subjects who developed an ulcer ( 85 percent of the hypersecretor group were correctly selected on the basis of psychological criteria) The study indicated that neither a higher rate of gastric secretion nor specific psycho-dynamic constellation was independently responsible for ulcers Together the two parameters constituted essential determinants in the precipitation of an ulcer on exposure to a social situation noxious to a specific individual

(B) Recent studies by WAdDELl (1956) as well as previous studies (BABKIN and SCHACTER 1950, Dragstedt et al 1950, Glass and Wolf 1950,), have suggested that a high level of gastro intestinal secretory and motor activity may be a function of a parasympathetic-sympathetic imbalance, associated with excessive vagal discharge Studies by WADDELL have also suggested that diflerences in urinary levels of catechol amines may be found in ulcer and non-ulcer patients and that these levels may reflect differences in sympathetico adrenal responsivity WADDELL's studies have been particularly concerned with the influence of catechol anmes and autonomic discharges on the gastric vasculature These investigations have been concerned with the reduction in gastric secretion associated with vasoconstriction of gastric vessels and the increase in gastric secretion associated with vasodilatation

In addition, other work by WADDELL (1956) has highlighted the role of the pyloric antrum in the acid secretory mechanism of the stomach He has reported that the recovery of acid is reduced by antral exclusion and sleeve resection of the mid portion of the stomach The magnitude of the effect on acid secretion is variable But the reduction of vagal secretion in a response to all stımuli may be profound Ulcer patients with antral resections secreted less acid under all conditions than ulcer patients with intact stomachs But they responded to varıous stımulı and maintained a $\mathrm{pH}$ well withın the range necessary to activate peptic digestion during all tests periods (WADDELL 1956)

It is believed that the rate of gastric secretion is dependent in large part upon the tonic state of the vagal reflex centers which in turn are maintained by the continuous inflow of afferent impulses from many areas, particularly the mouth area and the antral area of the stomach The principle effect of removal of the antrum in the experiments described by WADDELL is explained as a result of the withdrawal of an important source of afferent impulses which normally contribute heavily to the maintenance of a responsive state of reflex activity

The rclationship betwcen the antrum and the reflex control of gastric secretory activity is conceived as analogous to that which exists between the carotid body and the reflex centres that control blood pressure It is precisely this analogy which led the two research groups reporting in this paper to bring to bear their interests, experiences and techniques in an attempt to delineate some of the interrelationships between emotional, neurophysiological and gastric physiological factors

(C) Studies of catechol amıne and vascular correlates of specific emotional states In one series of investigations the influence of emotional states on compensatory vascular reflexes (carotid sinus, aortic, etc ) activated by physical and drug stımulı producing a hypotensive effect in the head and neck region was studied (COHEN 1959) Adrenalıne and noradrenalıne levels were assessed as an index of response of the sympathetic nervous system and adrenal medulla The experimental data suggested that catechol amine production was a determinant of or at least a correlate of an individual's vascular compensatory responses In addition, the type and intensity of emotion present during the experimental situation appeared to alter the response to a massive physiologic stressor (human centrifuge) 
or to produce a characteristic vascular response when a minimal vascular stımulus was introduced (Injection of small amount of parasympathetic mimetic drug) The effect of emotional arousal on vascular responsivity appeared to be mediated to a large extent by the differential release of adrenaline and noradrenaline Hypotensive responses occurred in conjunction with low excretory levels of urınary noradrenalıne and moderate or high excretıon levels of urınary adrenalıne Subjects demonstratıng this kind of vascular response pattern showed minımal aggressive behavior and a low level of angry, hostile, competitive feelings At the same time, they appeared to be markedly anxious Subjects with hypertensive responses show a mınımal to moderate degree of anxiety with marked angry, hostile feelıngs and noticeable display of aggressive behavior Their catechol amine excretion showed high levels of noradrenaline in the control and experimental specimens

The association of specific emotional state and behavioral mode variations with catechol amine levels and vascular responses was speculatively thought to be due to the activation of specific hypothalamic areas and the selective release of neuro-hormones It has been demonstrated by others that stımulation of specific hypothalamic areas causes the selectıve release of adrenalıne and noradrenalıne (Folkow and Eulev 1954) Furthermore there is evidence that cells in the adrenal medulla may release adrenaline and noradrenalıne independently and these cells may be innervated by different hypothalamic areas (Hillarp 1953) The work of Bard (1949), Chapman (1950), Gellhorn (1956) and Hess (1949) suggested other central mechanisms to account for the above relationships For example, it has been demonstrated that electrical stimulation of the cerebral corticdl, as well as, hypothalamic areas led to alterations in blood pressure In addition it had been suggested that the anterior and posterior hypothalamus may exert a tonic effect on medullary vasomotor regulatory centers Whether these areas are related to the hypothalamic areas which had been previously identified by direct stimulation studies as the areas excitıng anxiety or rage responses remains a moot question The evidence does suggest, however, that at least the adrenalıne producing areas of the hypothalamus are anatomically similar to those portions which previously had been identified as centers for fedr responses

The above work suggested that there may be central mechanısms mediating specific emotıonal responses and that these mechanisms may be related to neural circuits concerned with the release of catechol amines, as well as, the activation of portions of the autonomic nervous system

Urinary catechol amine levels were of interest then as possible correlates of specific behavioral modes and emotional states, as well as, bcing corrclates of gastric activity and duodenal ulcer formation

\section{EXPERIMENTAL METHODOLOGY}

\section{(A) Hypothesis and Approach}

The study which will be reported in this paper represents the combined effort of two research teams from two different universities utılızıng techniques permitting the independent evaluation of specific psychological factors, gastric secretion and catechol amine urinary levels in ulcer patients and control subjects The expcrimental physiological test situation was felt to have psychological implications which would highlight any psycho-dynamic differences between the two groups The psychodynamic factors were those that had previously been described in ulcer patients in other studies

It was hypothesized that a consistent relationship would exist between catechol amine levels and the presence or absence of duodenal ulcer as had been suggested by previous work by WADDELL and ZUIDEMA (1960). The previously identified relationship between specific psychological characteristics and catechol amine excretory rates was also anticipated in the subject population (CoHen, Silverman et al 1957, 1959). However, the psychological characteristics usually associated with various catechol amine levels were not expected in ulcer patients but would only be noted in those who showed characteristic catechol amine levels, as well as, an ulcer. The use of the psychologic criteria from the study of WEINER et. al. (1957) was an attempt to substantiate the findings of that study, as well as to suggest any relationships which might exist 
between the psychologic correlates of catechol amine excretion and the psychological correlates of peptic ulcers.

\section{(B) Experimental Design and Subjects}

Urine and gastric juice collectıons were carried out before and after admınıstration of peptone broth, histamine and insulin in 10 white, male ulcer patients and 10 white, male, non-ulcer control patients who were chosen by the group at the Massachusetts General Hospital without any communication with the research team at Duke The 10 ulcer patients had radiologically demonstrated active duodenal ulcers The control patients had no evidence of duodenal ulcer. Seven of the control subjects were normal, healthy volunteer subjects and the remaining 3 were hospitalized for illnesses other than duodenal ulcer (They had carcinoma of the rectum, chronic cholecystitıs and a cholangeitis secondary to partial stricture of the bile ducts.) The ulcer and non-ulcer populations were made up of hospitalized and ambulant individuals who were matched as far as possible for age and socio-economic status. The choice of 3 control subjects with gastro-intestinal disease was made in an effort to determine whether any psychological responses, noted on the tests and felt to be spec1fic for duodenal ulcers, might be associated with gastromtestinal diseases other than duodenal ulcer

Each subject was tested on 2 separate days, The test began each day at 730 a.m. after an overnight fast. On the first day, the subject waited and then lay quietly in bed with his head inclined at a 45 degree angle Most of this first hour was occupied with psychological testing After one hr, the subject stood beside the hed to void the first urine sample. Immediately after this, a Levine tube was passed to the stomach and adjusted to aspirate freely. Twenty min later, the collection of gastric juice was begun. Six 10-min "basal" samples of gastric juice were collected At the end of this period, the patient again stood to void a second sample of urine Both urine collections were referred to as "basal" samples After the second volding, $80 \mathrm{c} \mathrm{c}$. of peptone broth were introduced into the tube which was then clamped for $20 \mathrm{~min}$. The stomach was then emptied and six more 10-min samples of gastric juice were obtained At the end of this period, the bladder was again emptied. Histamine diphosphate $05 \mathrm{mg}$ was then administered subcutaneously and six more 10-min samples of gastric juice were collected At the end of the hour, a final collection of urine was made

On the second day of testing, a smilar routme was followed. After the first $2 \mathrm{hr}$ (during two "basal" urine samples and one "basal" gastric collections were obtained) 12 units of regular insulın were injected intravenously Thereafter, 30-min samples of gastric juice were collected and the patient voided $1 \frac{1}{2} \mathrm{hr}$ and $3 \mathrm{hr}$ after insulin administration Blood sugar concentrations were measured before the insulin was given and 30 and $60 \mathrm{~min}$ thereafter (It might be noted at this point that blood sugar concentrations were reduced to below $50 \mathrm{mg}$ per $\mathrm{c} \mathrm{c}$ in all ulcer patients and in all but one control patient )

After the final collection of the urine specimen on each day's testing, the subject was interviewed by a member of the surgical team using a list of nine questions which had been prepared by the group at Duke for this particular experiment. The interviewing was carried out by a member of the surgical team who had had previous experience with the use of interviews as an experimental tool.

The specific instructions for the administration of various psychologic tests (which 
will be described in subsequent sections) had been forwarded to the surgical group. The psychologic tests and interviews were recorded and the transcripts were forwarded to the group at Duke who evaluated them without any information regarding the patient's name or diagnosis, or any of the gastric secretory or catechol amine data. The transcripts were reviewed prior to their being forwarded to the group at Duke so that all possible cues which would suggest the presence of an ulcer or which would suggest whether the subject was a volunteer, healthy subject were removed from the protocols.

\section{(C) Measures}

\section{(1) Catechol amine excretion}

Immediately after the urine collections, the volume of each urine sample was measured and the entire specimen acidified to a $\mathrm{pH}$ of 23 with $6 \mathrm{~N}$ hydrochloric acid The samples were frozen and stored for later analysis The determination of adrenalıne and noradrenaline in these samples was made by DuToIT's (1959) modification of the fluorometric method of FLODDING and vON EULER (1956) utılizing a cation exchange resin method of purification *

\section{(2) Gastric secretıons}

The gastric specimens were examined $†$ for the volume in cc's per hour, $\mathrm{pH}$ of the specimen, free acid in mEquiv per 1 , free acid in mEquiv per hr, chloride mEquiv per 1 and chloride mEquiv per $\mathrm{hr}$

\section{(3) Psychological measures}

The first morning that the subject was tested, he was given a set of general instructions prior to the time that he was intubated Following the instructions, he was then given the following tests
(a) Focused Thematic Test
(b) Draw a Person Test
(c) Cards 2 and 3 from the Blacky Test
(d) Saslow Questionnaire
(e) Focused Interview

(a) Focused Thematic Test (Silverman et al 1957) The subjects were presented 4 cards from this test in sequence and were asked to make up a story for each picture The story did not have to be of any specific type After the subject had given a story, he was then asked to mention what events might have led up to the story in the picture and what was the possible conclusion

The stories that the subjects told in response to each card were scored on a 0 to $3-$ basis in the following areas (according to criteria described in previous publications)

(1) A behavioral mode of the hero (with an active, aggressive, mastering, impulsive description being scored $3+$ and a passive, yielding submitting hero scored 0 )

Behavioral mode score This score is obtained on the basis of a 0 to $3+$ scoring in the following areas

(a) The activity portrayed in the story as related to the cues which are actually presented in the picture

(b) Degree of independence or dependence demonstrated in the behavior of the hero while carrying out the activity of the story

(c) The level and type of aggressivity displayed in the behavior or thinking of the hero, considering the type of expressive mode, the directness of expression, the remoteness of expression

(d) The degree of discomfort with aggressive behavior feelıngs and ideas which are expressed

(c) The degrec of mastery that the hero demonstrates

* The fluorometric method was a modification of the VON EULER and FLODDING ferricyanıde modıfication of the Lund method Instead of using the vON EULER and FLODDING preferential oxidation technique, a multıple filter system was worked out for the simultaneous estımation of adrenalıne and noradrenaline

$\dagger$ After the measurement of the volume of each sample of gastric juice, the $\mathrm{pH}$ was determıned on a Beckman calomel glass electrode $\mathrm{pH}$ meter The acidity was titrated to a pH of 35 with $01 \mathrm{~N}$ in sodium hydroxide by an electrometric method and the chloride concentration was measured by the method of WILSON and BATLL (1928) 
(f) Impulsivity The more the hero of the story acts on a wish feeling, or impulse without restraint and without consequence, the higher is the score

The stories are graded on the basis of a scoring key A final "behavioral mode" score is tabulated by averaging the sum of all the above factors in all the stories so that a score is obtained for the behavioral mode on a $0-3$ continuum This score is considered a reflection of the behavioral mode of the subject on an aggressive-passive scale

(2) The emotional state (a clearly stated affect of anger or happiness is scored $3+$ and a clearly stated affect of anxiety or depression is scored 0 )

Emotional state score The emotional state of the hero is also scored The type of affect and the manner in which it is expressed are the major criteria used to obtain a score in this area If the affect is stated, the score is $3+$, strongly implied, $2+$, inferred, $1+$, and absent, $\mathbf{0}$ Each of four affects are scored separately anger, anxiety, depression, happy, satisfied content

The emotional state referred to the level of anxiety, anger and depression noted in the test protocols The behavioral mode was related to the direction, type, and intensity of aggressive expression It was thesc parametcrs which had been related in previous studies to the level of catechol amine (COHEN and SILVERMAN 1959; SilvermaN et al 1957)

Subjects with highest aggressıve behavioral mode scores, highest anger affect ratıngs, lowest anxious and depressed affect ratıngs were predicted to have the highest noradrenaline and lowest adrenaline excretions durıng the perıod of time that the tests were administered (Basal Period No 1 on Day 1)

The scores were further predicted to discriminate ulcer and non-ulcer patients if the catechol amine levels discriminated these patients

(b)(c)(d) Psychological test battery for "Hyper" and "Hypo" secretor factors D A P, Blacky Test and Saslow Questionnaire The D A P, Blacky Test and Saslow Questionnaire were used in this experıment because specific aspects of these tests had successfully discriminated in a previous study (WEINER et al 1957) (12) the subjects who had high pepsinogen levels and developed peptic ulcer from those with low pepsinogen levels who did not develop ulcers

(b) Draw a Person Test The drawnigs were evalualed by an "nidependent" rater who was given a series of categories to grade from the drawings The rater was not told how the scores would be correlated or with what measures it would be compared The rater's evaluation was then scored for the presence or absence of the following factors*

\section{Hypersecretor Factors}

Immature, boyish, asexual drawings

Male figure reflecting dependent, compliant, and oral needs

A dominant, controlling, or aggressive female figure

Diffuse anxiety and/or depressive features

\section{Hyposecretor Factors}

\section{Paranold features}

Pseudo-masculine features

Conflicts in the area of passivity and activity

The raters evaluation were scored as follows

$$
2+\text { - "hyper" secretor factor present or "hypo" secretor factors absent }
$$

$1+-$ if it was equivocal

0 - "hyper" secretor factor absent or "hypo" secretor factor present

Patients with peptic ulcer were predicted to have a higher "hyper" secretor score than control subjects A mean score over $1+$ was categorized as "hyper" secretor and lower than $1+$ as "hypo" secretor

(c) "Blacky" Test The subject was given the same instructions as on the F T T Cards 2 and 3B were used since they most accurately discriminated the high and low pepsinogen secretor subjects in the study of WIENER et al (Expression of anger on Card 2 and denial of aggression on card 3B)

* Dr B M Shmavonian, Chief Psychologist of the Division of Psychophysiologic Research of the Department of Psychiatry, Duke University Medical Center, rated the test protocols He had not been a participant in this project and had no information other than a list of categories on which he was asked to score the drawings 
The test was scored in a manner similar to that described in WEINER et al paper However, there were slight modifications based on the scoring techniques used by the investigators in evaluating angry affect and aggressive behavioral mode for projective test stories

Subjects directly expressing anger and describing aggressive behavior consistent with the degree of anger expressed were predicted to be the least likely to have an ulcer (or low in hypersecretor factors ) $1 \mathrm{e}$ they were scored 0 for hypersecretor

Discomfort with anger and/or agression was interpreted on the basis of the absence of both from the stories or an inconsistency between the angry affect and aggressive behavior described The subjects with the highest level of discomfort were predicted to be most likely to have an ulcer (on $2+$ "hyper" secretor score)

(d) Saslow Questionnaire (32) This questionnaire required the subject to indicate by a "yes", "usually", "often", "rarely", "never", reply his abılity to express and handle angry and anxious feelings *

The subject was asked to encircle one of the above responses which most closely matched therr fcclings

There was a series of questions related to anger and a series related to anxiety which required the subject to state whether they express these feelings immediately, whether they suppress feelings, whether they express as much as they feel, whether they express the feeling to the person who created the feeling " They are then asked if they hold in their feelings, do they feel ill " If they answer "yes" to this question, they are then asked to circle any symptoms which are listed (GiLDE4.1949) which develop when they hold in their feelings

Immediate, direct and complete expression of either feelıng was scored $\mathbf{0}$ fur hypersecretor factors The suppression of feelings with an indication that somatic symptoms developed when emotionally aroused and the indication of four or more symptoms in the list presented on the questionnaire were scored as hypersecretor factors and where predicted to be found in patients with ulcers Hence, the subjects who described the most difficulty with the outward expression of emotions (anger and anxiety) and the largest number of somatic symptoms when emotionally aroused were predicted to be most likely to have an ulcer

(e) Focused Interview Following the gastric secretory and urine collections on each of the two days, the subjects were interviewed by one member of the surgical team The interview was recorded and the transcript was typed, it was carefully reviewed in order that all cues be removed which might suggest whether the subject had an ulcer or whether the subject was a volunteer The interview was structured and consisted of a series of nine questions which has been prepared by the research team at Duke

The questions were focused on the subject's perception of the test situation, the examıners, and the individual test stimulı The behavior and feelings which the subject experienced were explored An attempt in general was made to evaluate two major areas

(1) The emotions which the subject experienced as indicated by the verbalizations of the subject during the interview, as well as, the associations of the subject The purposes of the question was to highlight the emotions experienced in relation to the test situation and the test stimuli The impulses and feelings which were aroused were evaluated with a particular attempt made to determine the kind of psychologic adaptational or defensive mechanisms which the subject utilized to master the experimental situation

(2) The fact that a tube was placed in the gastrontestinal tract after the subject had been required to fast for twelve hours and the fact that the subjects were dependent on medical authority figure, either in relation to the test or the treatment situation, were considered "orally" significant stımuli. Because of this, it was felt that the psychodynamic behavioral and thought patterns usually noted in patients with a peptic ulcer should be exaggerated when their thoughts, feelıngs, expectations, and reactions to the experimental situation were explored

The responses of the subjects to the interview questions were compared and evaluated on the basis of some of the psychologic factors described as discriminating the ulcer and non-ulcer (as well as hyper and hyposecretor) groups in the study by WeINER et al (1957) Predictions were made as to whether the subject was an ulcer patient or a non-ulcer patient on the basis of the amount of "hypersecretor" psychologic type factors which were noted in the interviews

* The questionnaire used in this study was a slight modification of the original questionnaire The criteria of prediction were based on the study reported by WeINER et al and not those from the original study of SASLOW 
The questions were

What did you think of the test?

How did you feel during the test?

What did you think the test was for?

How do you think it could be made casicr?

What did you thınk about the tube? Needle? And what kınd of reaction did you have from the tube? Needle? Injection?

What did you think is the most important reason for giving this test?

What would be the most important thing that could result from this test?

Have you ever been exposed to a situation similar to this? How did you feel? Did you ever experience feelıngs like you did durıng this test regardless of whether it was a similar situation or not?

Have you found out this test did not show anything important or would not be helpful to you, how would you feel ?

The criteria of predictions for the interview were

(1) Perception of test situation, examiners and test procedures It was predicted that patients with peptic ulcers would percerve the test situation as

(a) a source of help, $\mathrm{e}$ e as a situation which would bring them personal benefit either as a treatment or leading to a treatment which would help him or that the test would help by leading to a diagnosis of his condition (with the implication that he would then be helped )

It was thought that the ulcer patient would express a need for external help which his dependency on the test would reflect There would be no indication of a wish to master the test situation and there would be a denial of any bodily discomfort produced by the test

(b) the non-ulcer patient would be more prone to perceive the testing situation as a competitive one in which there would be attcmpts by the paticnt to demonstrate their ability to mastcr it Furthermore, this might be shown by attempts to deny that the test was hard or that they were hurt in any way

They would perceive the test more impersonally and not expect any direct benefits The non-ulcer patient would not feel the test was beneficial personally although he might state it had some value as a therapeutic, diagnostic or research tool

(c) The ulcer patient would further perceive the test situation in terms of their preoccupations with the tube ( $\mathrm{g}$ as a source satsifyıng or leading to satisfaction of their needs to be fed, taken care of In contrast to this, the non-ulcer patient might show more concerns with the psychologic test portion of the experiment, concerns about having their personality investigated, having things about them revealed and demonstrate a high degree of suspiciousness This prediction was based on the more frequent occurrence of paranoid trends (e $g$ suspiciousness) in the hyposecretor group in previous investigations (WEINER et al 1957)

(2) The ulcer subjects would show a greater tendency to accept the authority of doctors and hospital personnel without question and without complaint The ulcer subject would demonstrate a greater tendency to submit and passively yıeld to the wishes of external objects, particularly authorities The ulcer subject would show a greater tendency to comply with the wishes of the authorities and submit to unpleasant procedures without complaint He would also show a greater tendency to please and placate authorities

(3) The subjects who demonstrated an emotional state of high anxiety, particularly if it occurred in relationship to areas which appear most relevant to oral dependency conflicts, then the more likely the subject was to have peptic ulcer This was even more likely if they also showed an inhibition or denial of aggressive impulses and angry thoughts about the test situation There would be greater tendency in the ulcer patient to deny any expression of affect There would be more evidence noted in the ulcer patient of many maneuvers to obtain or retain the external support and not express their angry feelıngs Hostility which was aroused would produce anxiety and guilt and would be handled by a denial, internalization, rationalızation and displacement

The subjects without peptic ulcers would be most likely to react to sources of discomfort with hostility which they are able to express more easily than the ulcer patients The non-ulcer subjects would also demonstrate fewer problems in regard to dependency and less dependency on the external authorities

(4) It was predicted that the non-ulcer patient or the hyposecretor would show a greater amount of pseudo-masculıne trends with attempts to demonstrate masculine over-compensation or defenses 
against hostile feminıne identıfication This would be associated with more problems referable to masculınity and feminity, activity in passivity as well as conflicts over sexual identification.

(5) The non-ulcer patient would display more conflicts, wishes or needs in relation to narcissism Associated with this, they would exhibit more problems relative to internal bodily discomfort

\section{RESULTS}

\section{Differences between Ulcer Patients and Control Subjects}

\section{(A) Psychological Test Battery for "Ulcer"Psychodynamic Characteristics}

(1) Draw-A-Person Test. Nine patients and 10 controls completed the D.A P. Test. Table 1 shows the results of the evaluations of the criteria mentioned with previous section

\begin{tabular}{|c|c|c|}
\hline & $\begin{array}{l}\text { Predicted to have } \\
\text { ulcer ("hyper") }\end{array}$ & $\begin{array}{l}\text { Not predicted to have } \\
\text { ulcer ("hypo") }\end{array}$ \\
\hline $\begin{array}{l}\text { Subjects with } \\
\text { ulcer }(N=9)\end{array}$ & 7 & 2 \\
\hline $\begin{array}{l}\text { Control subjects } \\
(N=10)\end{array}$ & 2 & 8 \\
\hline
\end{tabular}

TABLE 2 -Prediction OF ULCER "HYPER" AND "HYPO" SECRETOR SCORES ON SASLOW

\begin{tabular}{c|c|c}
\hline & Hypersecretor & Hyposecretor \\
\hline $\begin{array}{l}\text { Ulcer } \\
(N=9)\end{array}$ & 6 & 4 \\
\hline $\begin{array}{l}\text { Control } \\
(N=10)\end{array}$ & 3 & 6 \\
\hline
\end{tabular}

A Chi Square test of the significance of difference of ulcer and control subjects for "hyper" secretor scores vs "hypo" secretor was significant at 005 level $(P=005)$.

(2) Saslow Questionnatre. Nine ulcer subjects and 10 control subjects completed this questionnaire Table 2 shows the distribution of the subjects' scores on this questionnaire in regard to their being in the hyper or hyposecretor range on the basis of the criteria described previously

A Chi Square test of difference of ulcer and non-ulcer group for hypersecretor scores and hyposecretor scores was not significant.

(3) Blacky Test. The scores of 10 ulcer and 10 control subjects are listed on Table 3

Difference of ulcer and control subjects the number of "hyper" secretor scores vs. "hypo" secretor was significant at $P=001$.

(4) Overall Ratıng on combined "hyper" and "hypo" secretor scores of D A.P. Blacky and Saslow. The average of the actual scores of the 10 ulcer and 10 control subjects on all three tests for "hyper" and "hypo" secretor factors is shown on Table 4. 
When the score for all 3 tests was determined, the difference in the control and ulcer group was significant wilh $P=0.05$.

\section{(B) Post-Test Interview Ratings}

The replies of 10 ulcer and 10 control subjects to the nine questions asked in the post-experimental interview were scored on the basis of "hyper" and "hypo" secretor psychological factors derived from the study reported by WEINER et al. (1957) and modified by the investigators for the specific experimental situation.

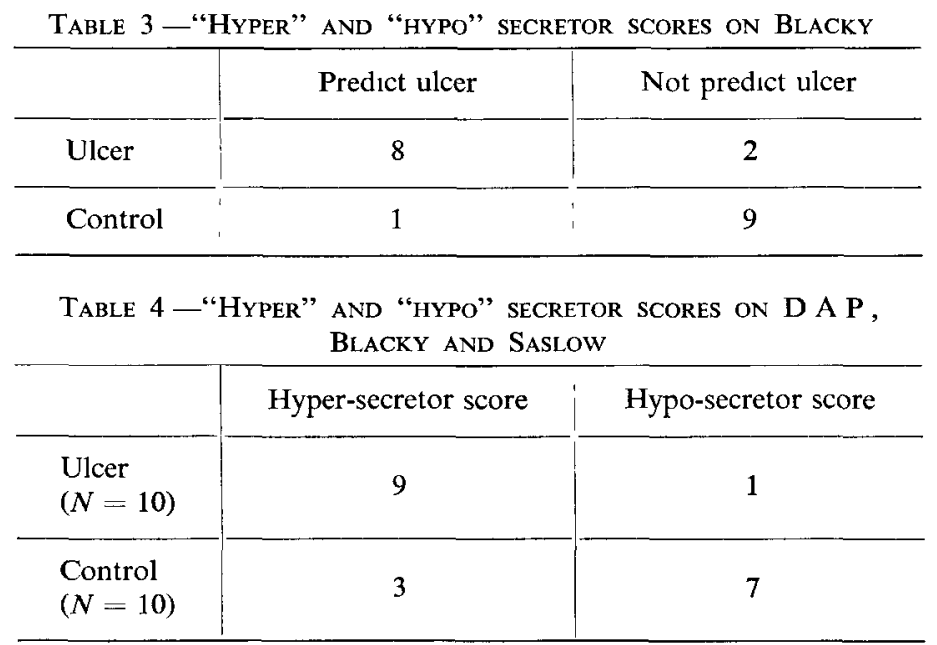

Each expression or statement cvaluated as a "hyper" sccrctor factor was scorcd $(+)$ and each statement evaluated as a "hypo" secretor factor was scored (-)

The final score for each factor was obtained by adding the number of times it had been identified in the subjects' responses to the nune questions. Table 5 lists the sum of the ulcer patients and control subjects' score in each of the eight areas which were evaluated in the nine questions. The total scores of each individual subject is also shown on Table 5. The total score for each individual was obtained by adding the total hypersecretor factor scores $(+)$ and subtractıng the sum of the hyposecretor factor scores (-) Subjects with a final score in $(+)$ range (hypersecretors) werc predicted to be most likely to have an ulcer and subjects with a score in (-) range were predicted to be least likely to have an ulcer

The subjects' interview responses were scored separately on each day. The data presented in this paper which is charted on Table 5 is a summary of the overall score of the first and second day interviews. Later publications will compare the psychological, physiological and endocrinological responses of the first and second test day.

The table shows that 9 of the ulcer patients had hypersecretor scores $(+)$ and 9 of the control patients had hyposecretor scores $(-)$. The difference between the groups was significant (using a Chi Square test, $P<0 \cdot 001$ ).

The subjects have been listed so that they are rank ordered from highest "hyper" secretor score $(+)$ to lowest "hypo" secretor score $(-)$. The result is rather striking in that except for one tie (an ulcer and control subject with rank order of 10.5 and scores of -1 there is a perfect division of ulcer and control subjects. 


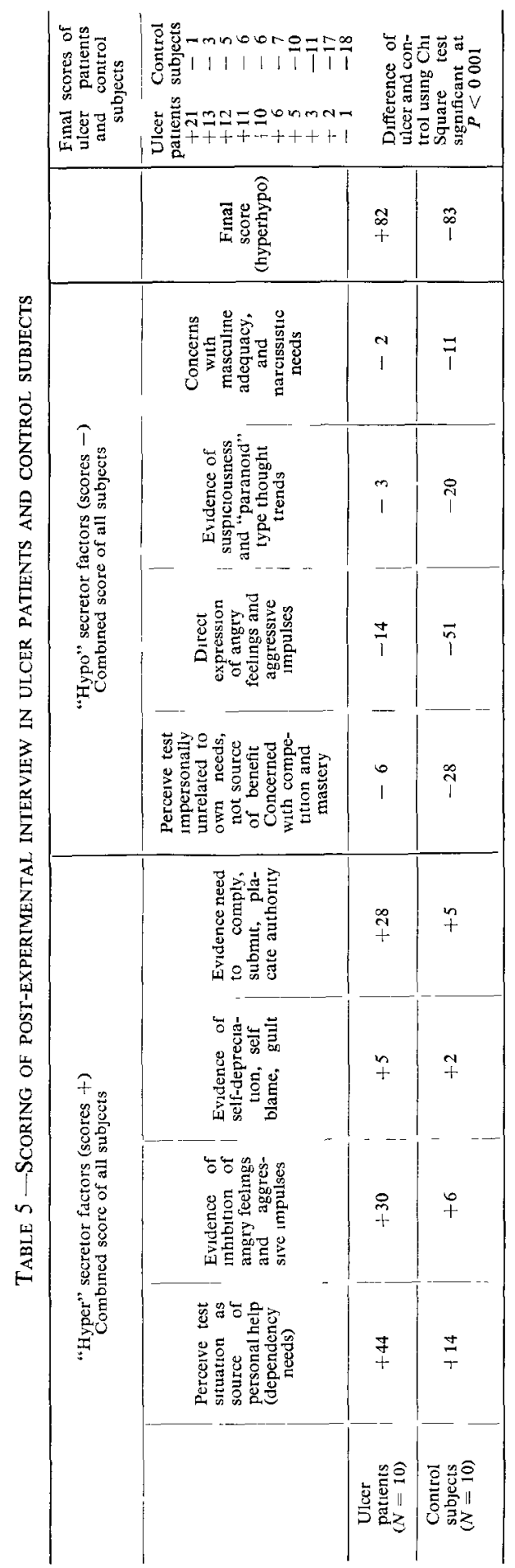


For a "factor" to be scored in the subject's answer, clear and durect evidence has to be noted. If a statement or expression implied or inferred some feeling or percept, it was not scored.

Some illustrations of the type of expression which were scored and expressions which were not scored are illustrated in the following section

Question 1 What did you think of the test?

Control subject "The tube was a bit uncomfortable, the rest went all right"

(1) Expression of discomfort- "Hyposecretor" factor (-)

Ulcer pattent "I think the doctors are trying to do right My gettıng into such a condition that's why l'm the patient"

(1) Self-depreciation $(+)$

(2) Placate doctors $(+)$

(1) and (2) "hypersecretor" factors $2(+)$

(3) Implied need for dependency and help from doctors-not scored

Question 2 How did you feel during the test?

Control subject "It was a little inconvenıent having that tube down there I felt like I wanted to swallow and couldn't, but I didn't feel any pain "

(1) Expresses discomfort with test

(2) Concern in area of mastering situation and being an adequate male ( $1 \mathrm{e}$ wish to be able to act, not be overwhelmed or feel pain)

(1) and (2) "hyposecretor" factors $2(-)$

Ulcei patient "I felt it was worthwhile and for my benefit"

(1) Perceives test as being source of help for him 1(t)

Queshon 3 Whial did you think the lest was for?

Control Subject "I know it must be some kınd of research I wouldn't imagine what the tube had to do with the pictures I couldn't connect the two, it had me baffled "

(1) Perceives test in impersonal manner of no direct benefit to him 1(-)

(2) Concerned about inability to understand and master situation $1(-)$ Scored for two hyposecretor factors $2(-)$

Ulcer Patient "To find out what's wrong with me"

(1) Perceives test as being source of personal help Scored for hypersecretor factor $1(+)$

Question 4 "Could you think of any way test could be made easier?"

Control Subject "Probably make it shorter"

(1) Expresses criticism Score for hyposecretor factor 1(-)

Ulcer patient "In my estımation couldn't make it better"

(1) Need to placate Scored for hypersecretor factor $1(+)$

Question 6 "What do you think was the most important reason for giving this test" "

Control Subject "To explore my case so that I might be used for future records" (This control subject was hospitalized with Carcinoma of the rectum)

(1) Test not seen as source of personal help (-)

(2) Suggestion of feeling of being exploited Implied but not scored as hyposecretor factor.

Ulcer Pattent "To see my functioning and my trouble and to see best way to cure it"

(1) Test seen as source of personal help Scored for hypersecretor factor $(+)$

Question 7 "What would be the most important thing that could result from this test ""

Control Subject "To make it easier for doctors to diagnose ulcers You might have learned somethung"

(1) Perceives test as being useful to doctors, not himself Score for hyposecretor factor (-)

Ulcer Pattent "To help me be myself"

(1) Test perceived as source of help for patient Score for hypersecretor factor $(t)$ 


\section{(C) Focused Thematıc Test}

The scores on this test were expected to relate to the ratio of catechol amines in the subjects' urine In previous studies, the subjects whose test responses had been scored as demonstrating a high level of aggressive impulses and angry affect had been found

TABLE 6 - RELATIONSHIPS OF SCORES ON FOCUSED THEMATIC TEST (FTT)

(A) Correlation of F T T score, catechol ammes and gastric secretion

\begin{tabular}{|c|c|c|c|}
\hline \multirow[b]{3}{*}{$\begin{array}{l}\text { Rank order of scores on } \\
\mathrm{F} T \mathrm{~T} \text { (High rank order } \\
\text { for score reflecting ag- } \\
\text { gressive behavioral mode, } \\
\text { anger and low anxiety }\end{array}$} & \multirow[b]{3}{*}{ Correlated with } & Rank order of & $\begin{array}{l}\text { Correlation and } \\
\text { significance }\end{array}$ \\
\hline & & $\begin{array}{l}\text { Total catechol amıne level } \\
\text { and adrenalıne \% durıng } \\
\text { psychologıcal test perıod } \\
\text { (Basal Day 1) }\end{array}$ & $r_{s}=-057<002$ \\
\hline & & $\left.\begin{array}{c}\text { Total catechol amine level } \\
\text { and adrenalıne \% } \\
\text { (a) "Basal" specimen day } \\
1 \text { \& } 2 \text { combined- } \\
\text { (b) After insulin- } \\
\text { (c) All specimens- } \\
\text { Gastric secretion (volume } \\
\text { and free acid) } \\
\text { (a) Durıng basal day } 1 \\
\text { psychological tests- } \\
\text { (b) "Basal" day } 2- \\
\text { (c) Basal day } 1 \text { \& } 2- \\
\text { (d) After stimulation- } \\
\text { (e) All specimens- }\end{array}\right\}$ & $P=\mathrm{NS}$ \\
\hline
\end{tabular}

(B) Prediction of ulcer from F T T score

\begin{tabular}{c|c|c}
\hline & $\begin{array}{c}\text { Predict ulcer } \\
\text { (Low aggression and anger, } \\
\text { high anxiety score) }\end{array}$ & $\begin{array}{c}\text { Not predict ulcer } \\
\text { (High aggression and anger, } \\
\text { low anxiety score) }\end{array}$ \\
\hline $\begin{array}{c}\text { Ulcer patients } \\
(N=9) \\
\text { Control subjects } \\
(N=10)\end{array}$ & 4 & 5 \\
\hline
\end{tabular}

$$
P=\mathrm{NS}
$$

to have high level of nor-adrenaline excretion and low level of adrenaline excretion in urinary specimens. Subjects who presented stories which were scored as showing a high level of anxicty, a low level of anger and aggressive impulses had low urinary level of nor-adrenaline and high level of adrenaline. Hence the correlation which was expected in this study was between the FTT score and the catechol amine levels.

It was expected that if the catechol amine levels showed significant differences in ulcer and control subjects, then a correlation might be found between FTT score and the presence or absence of ulcer. 
The correlation of the scores on the FTT and the catechol amıne urinary excretion is seen on Table 6 The catechol amine levels charted for Day 1, Basal Period 1, are those which were obtained from the urine specimens collected during the time the psychological tests were being taken.

The subjects' FTT scores were rank ordered on the bases of their behavioral mode and emotional state score The subjects' catechol amine levels were rank ordered on the bases of the total catechol amıne level and the percentage of adrenalıne because in previous studies, the FTT correlated with the ratıo as well as the level of adrenalıne and noradrenalıne Hence, a high catechol amıne level and a low adrenalıne percentage had the highest rank order

TABLE 7 - Prediction OF UlCER FROM ALL PSYCHOLOGICAL MEASURES

\begin{tabular}{|c|c|c|c|c|c|c|}
\hline & $\begin{array}{c}\text { Draw } \\
\text { a } \\
\text { person } \\
\text { test }\end{array}$ & $\begin{array}{c}\text { Saslow } \\
\text { questionnaire }\end{array}$ & $\begin{array}{c}\text { "Blacky" } \\
\text { test }\end{array}$ & $\begin{array}{l}\text { Focused } \\
\text { interview }\end{array}$ & F T T & $\begin{array}{l}\text { Prediction based } \\
\text { on average } \\
\text { rating on all } \\
\text { measures }\end{array}$ \\
\hline $\begin{array}{l}\text { Ulcer } \\
\text { patıents }\end{array}$ & $\begin{array}{c}7 / 9 \\
\text { predicted to } \\
\text { have ulcer }\end{array}$ & $\begin{array}{c}6 / 9 \\
\text { predicted to } \\
\text { have ulcer }\end{array}$ & $\begin{array}{c}8 / 10 \\
\text { predicted to } \\
\text { have ulcer }\end{array}$ & $\begin{array}{c}9 / 10 \\
\text { predicted to } \\
\text { have ulcer }\end{array}$ & $\begin{array}{c}4 / 9 \\
\text { predicted to } \\
\text { have ulcer }\end{array}$ & $\begin{array}{c}9 / 10 \\
\text { predicted to } \\
\text { have ulcer }\end{array}$ \\
\hline $\begin{array}{l}\text { Control } \\
\text { subjects }\end{array}$ & $\begin{array}{c}8 / 10 \\
\text { not predicted } \\
\text { to have ulcer }\end{array}$ & $\begin{array}{l}6 / 10 \\
\text { not predicted } \\
\text { to have ulcer }\end{array}$ & $\begin{array}{l}9 / 10 \\
\text { not predicted } \\
\text { to have ulcer }\end{array}$ & $\begin{array}{l}10 / 10 \\
\text { not predicted } \\
\text { to have ulcer }\end{array}$ & $\begin{array}{l}8 / 10 \\
\text { not predicted } \\
\text { to have ulcer }\end{array}$ & $\begin{array}{l}9 / 10 \\
\text { not predicted } \\
\text { to have ulcer }\end{array}$ \\
\hline $\begin{array}{l}\text { Significance using } \\
\text { Chi Square }\end{array}$ & $P=005$ & $P=\mathbf{N ~ S}$ & $P=001$ & $P=0001$ & $P=\mathrm{N} \mathrm{S}$ & $P<001$ \\
\hline
\end{tabular}

The correlation coefficient between FTT score and catechol amınes was 057 which was signıficant at better than the 002 level, but less than 001 level

Table 6 also shows the relationshıp of FTT scores to the catechol amine levels and adrenalıne per cent found

(a) in the urine specimen of "Basal" day 1 and Day 2 combined

(b) in the urine specimen after insulin injection (The insulin injection was assumed to be a stimulant to the hypothalamus )

(c) in the average of all urine specimens

The correlation described previously was between the FTT score and the catechol amine level in the urines collected during the tıme the FTT was being taken From the results which are shown, it can be seen that the FTT score correlated only with the catechol amine levels during the time the tests were being administered

The relationship of FTT scores with the presence or absence of ulcers is indicated at the bottom of Table 6 The subjects who had high aggressive behavioral mode and high anger and low anxiety scores were predicted to be least likely to have ulcer (If high noradrenaline levels were found in the control subjects and low noradrenaline levels found in ulcer patients ) The FTT did not discriminate ulcer and non-ulcer subjects

The scores on the FTT were compared with the scores on the psychological test battery for "hyper" and "hypo" secretor factors (DAP, Saslow and Blacky A rank order correlation was done and a negative correlation was found $\left(r_{s},-036\right)$ The correlation just missed being significant at a 005 level $\left(r_{s},-0377\right.$ would have been significant at a 005 level $)$

The scores on the FTT showed no correlation with the actual gastric secretion* of the subjects during the test period

\section{(D) Predictions from All Psychological Measures}

Table 7 summarizes the differences between ulcer and control groups in the psychological areas tested. The table lists the predictions based on a score derived from a consideration of all psychological measures. The subjects' final scores on each test $(++$ score for hypersecretor, + equivocal and 0 for hyposecretor range) were averaged and a final score for all psychological measures was obtained.

* Gastric secretion refers to the total volume an the free acid (mEquiv/l) 
On the basis of this score, 9 out of 10 ulcer and 9 out of 10 control subjects were correctly predicted. The significance of difference using a chi square test was significant at better than a 0.01 level $(P<0.01)$

None of the scores on the psychological tests individually (DAP, Saslow, Blacky, FTT) or the score of combined test battery correlated with the gastric volume and free acid secreted during the time the tests were administered.

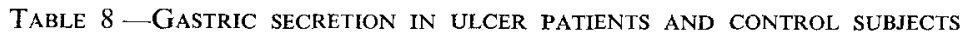

\begin{tabular}{l|l|c|c}
\hline Experimental period & Measure & Ulcer patients & Control subjects \\
\hline "Basal" & $\begin{array}{l}\text { *Volume } \\
\text { fFree acid } \\
\text { Day 1 }\end{array}$ & $\begin{array}{l}52 \pm 65+ \\
15 \pm 5\end{array}$ & $\begin{array}{r}55 \pm 99 \\
23 \pm 69\end{array}$ \\
\hline After pepton & Volume & $97 \pm 17$ & $79 \pm 144$ \\
broth & Free acid & $50 \pm 75$ & $40 \pm 109$ \\
\hline After & Volume & $134 \pm 185$ & $104 \pm 17$ \\
histamine & Free acid & $77 \pm 7$ & $59 \pm 122$ \\
\hline "Basal" & Volume & $68 \pm 149$ & $52 \pm 122$ \\
Day 2 & Free acid & $30 \pm 63$ & $15 \pm 44$ \\
\hline After & Volume & $114 \pm 172$ & $79 \pm 135$ \\
insulin & Free acid & $60 \pm 69$ & $44 \pm 107$ \\
\hline
\end{tabular}

* Volume in $\mathrm{ml} / \mathrm{hr}$

$\uparrow$ Free acid in mEquiv/hr

$\ddagger(\perp=$ Standard error $)$

None of the Differences were significant at $P=005$ level using the Chı Square test

The rank order correlation of the scores of the subjects' pre-intubation psychological test battery for "hyper" and "hypo" secretor psychological factors and the "hyper" and "hypo" secretor scores on the post intubation interviews was significant. $\left(r_{s}=\right.$ $+0.63, t=344$ and $P<0001$ )

\section{(E) Gastric Secretion in Ulcer Patients and Control Subjects}

The gastric secretory data will only be summarized in this paper A more complete presentation of the data and a more thorough discussion of the data can be found in other publications. WADDELL et al (In press)

Table 8 summarizes the mean values (and standard errors) of some of the gastric secretory data of the 10 ulcer patients and 10 control subjects The values were obtained during the "Basal" periods of Day 1 and 2, after a peptone broth, histamine and insulın stımulation

Values for the total volume (cc/hr) and free acid (mEquiv/l) are shown Free acid (mEquiv/hr) and chlorides (mEquiv/1 and mEquiv/hr) were also determıned, but are not shown on this chart*

The mean total volume and mean titratable acidity of the gastric juice were higher and the mean $\mathrm{pH}$ was lower in almost all periods for the ulcer patients than for the control patients, however, the variation was marked, and only one of the differences between the ulcer and control group even reached even an 01 level of significance with a two-tarled test (The " $P$ " had to reach 005 level to be considered significant) Hence, there were no striking differences in the gastric secretory values when the ulcer and control subjects as a group were compared, although rather marked individual differences were noted

* These values did not indicate anything different than observations noted with free acid (mEquiv/I) and volume They have been omitted for the sake of brevity. 


\section{(F) Catechol Amine Excretion}

Tables 9 and 10 summarize the results of catechol amıne excretion durıng basal periods and after stımulation

(1) Noradrenalıne Levels (Table 9) (a) "Basal" Perlod The dıfference between the two groups with respect to excretory rate of noradrenalıne reached the 002 level of significance with the control

TABle 9 -Noradrenaline URINARY EXCRETory LeVELS IN ULCER PATIENTS AND CONTROL SUBJECT $(\mu \mathrm{g} / \mathrm{hr})$

\begin{tabular}{|c|c|c|c|c|c|}
\hline & \multirow{2}{*}{ "Basal" } & \multirow{2}{*}{$\begin{array}{c}\text { After } \\
\text { peptone }\end{array}$} & \multirow{2}{*}{$\begin{array}{c}\text { After } \\
\text { histamine }\end{array}$} & \multicolumn{2}{|c|}{ After insulın } \\
\hline & & & & $(0-90 \mathrm{~min})$ & $(90-180 \mathrm{mın})$ \\
\hline \multicolumn{6}{|l|}{$\begin{array}{l}\text { Control } \\
\text { subjects }\end{array}$} \\
\hline Mean & 238 & 239 & 245 & 312 & 249 \\
\hline S E & \pm 036 & $\pm \mathbf{0} 40$ & \pm 051 & \pm 060 & \pm 064 \\
\hline \multicolumn{6}{|l|}{$\begin{array}{l}\text { Ulcer } \\
\text { patients }\end{array}$} \\
\hline Mean & 131 & 085 & 240 & 148 & 088 \\
\hline S E & \pm 020 & \pm 031 & \pm 083 & $\perp 023$ & \pm 024 \\
\hline$t$ value & 260 & 305 & 005 & 255 & 234 \\
\hline$P$ & 002 & 001 & N S & 005 & 005 \\
\hline
\end{tabular}

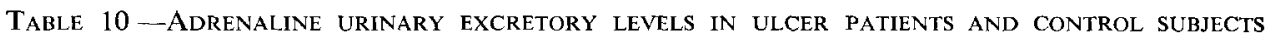
( $\mu \mathrm{g} / \mathrm{hr})$

\begin{tabular}{|c|c|c|c|c|c|}
\hline \multirow[b]{3}{*}{$\begin{array}{l}\text { Control } \\
\text { subjects }\end{array}$} & \multirow{2}{*}{ "Basal" } & \multirow{2}{*}{$\begin{array}{l}\text { After } \\
\text { peptone }\end{array}$} & \multirow{2}{*}{$\begin{array}{c}\text { After } \\
\text { histamine }\end{array}$} & \multicolumn{2}{|c|}{ After insulın } \\
\hline & & & & $(0-90 \mathrm{~min})$ & $(90-180 \mathrm{~min})$ \\
\hline & & & & & \\
\hline Mean & 050 & 063 & 037 & 318 & 253 \\
\hline $\mathrm{SE}$ & \pm 009 & \pm 026 & \pm 010 & \pm 10 & \pm 053 \\
\hline $\begin{array}{l}\text { Ulcer } \\
\text { pattents }\end{array}$ & & & & & \\
\hline Mean & 032 & 033 & 068 & 236 & 122 \\
\hline SE & \pm 006 & \pm 008 & \pm 041 & \pm 038 & \pm 028 \\
\hline$t$ value & 165 & 109 & 073 & 076 & 218 \\
\hline$P$ & N.S & N S & N S & N S. & 005 \\
\hline
\end{tabular}

subjects excretıng higher levels than the ulcer patients (b) "Stımulatıon" Periods During periods of stimulation with peptone broth and insulin, the mean noradrenaline output of the ulcer patients was lower than that of the control patients The difference in noradrenaline levels for the control and ulcer patients after peptone administration was significant at 001 level Ninety minutes after insulın administration, the differences were significant to the 005 level and $90-180 \mathrm{~min}$ after insulın, the differences were significant to a 005 level In all instances, the differences were characterized by a higher level of noradrenaline in the control subjects than in the ulcer patıents Orily after the 
administration of histamine was there no significant difference noted and the mean levels of noradrenaline in the ulcer and control subjects were almost identical

(2) Adrenaline levels The mean adrenaline levels were higher in the control subjects than in the ulcer patients, but there was much less consistency and much greater overlap than in the case of noradrenalıne The difference in adrenalıne level durıng the "Basal" perıods was not significant After peptone broth, there was no significant difference and this was also true after the histamine period In fact, the adrenaline levels in ulcer patients were higher than the adrenaline levels in the control patients after the admınıstration of histamine (This was the only instance when this occurred) 90 mın after insulın there was no significant difference between adrenalıne levels of ulcer and control groups However, (180 min after insulın, the control group's level was higher than that of ulcer group The difference was significant $(P=005)$

(3) Response to insultn The ulcer patients had lower noradrenalıne excretory rates than the control patients before the injection of insulın and during the first ninety minutes following the injection the difference between the two groups became more pronounced However, the difference in mean response to stimulation by hypoglycema between the ulcer and control groups did not attain statistical significance at the 005 level but was significant only at 01 level Nevertheless, the trends suggested by the data were that a state of hypoglycemia produced by insulın injection led to a more marked change in noradrenaline level in the control group

(4) Response to histamine The responses of the two groups to Histamıne was striking in that this was the only situation in which the level of noradrenaline in the ulcer group was not significantly lower than the level of noradrenaline in the control group

The average response of the two groups was as follows

\begin{tabular}{c|c|c}
\hline Mean level before histamine injection & Mean level after histamıne & Mean response \\
\hline Noradrenaline & & $+15 \mu \mathrm{g}$ \\
Ulcer-09 $\mu \mathrm{g} / \mathrm{hi}$ & 24 & $+03 \mu \mathrm{g}$ \\
Control-24 & 27 & \\
\hline Adrenalıne & & +04 \\
Ulcer-0 $3 \mu \mathrm{g} / \mathrm{hr}$ & 07 & -02 \\
Control-06 & 04 & \\
\hline
\end{tabular}

The mean response difference did not attain any statistical significance due to the marked variation in the degree and direction of response withın each group and the overlap between groups

(5) "Basal" specimen The comparison between "basal" catechol amıne output of ulcer and control patients reported in previous section is not based on single samples, but on the combined figure of four separate specimens (pre and post intubation resting specimen on Day 1 and Day 2) This multıple sampling techinique was used to mininize the influence of factors associated with changes in test environment, which might influence the catechol output

When the four "basal" specimens were considered separately, the noradrenaline level in the ulcer patient was found to be lower than that of the control subject at a 005 level for three of the specimens and one at 01 level (not significant) using two-talled test

Three of the four comparisons indicated a lower adrenaline output in ulcer patients but none of these differences were statıstically significant

(6) Urne volume The results strongly suggested that ulcer patients had lower mean noradrenaline urinary levels under basal conditıons, after peptone broth and insulin stımulation However, these results could be influenced by a lower urme volume in ulcer patients or in a correlation between the noradrenalıne urinary levels and urıne volume

A Spearmen rank order correlation between the level of noradrenalıne and urine volume revealed low positive correlations.

(a) Under basal conditions rho $=+025$

(b) After Peptone broth rho $=+032$

$\begin{array}{ll}\text { (c) After insulin } & \text { rho }=+018\end{array}$ 
None of these correlations even reached a 01 level of significance using a two-tarled test and all were too small to be considered of any consequence

The fact that the ulcer patients tended to have lower urme volumes than the control subjects led to additional analysis being carried out based on an index of catechol output divided by urine volume These analysis indicated that ulcer patients tended to excrete less noradrenaline per unit of urine than did the control subjects under all conditions The differences were statistically significant, however, only after stimulation with Insulin

(7) Influence of enuronmental factors on catechol amine excretion The catechol collections were made under a variety of conditions which might have influenced catechol output. For example, the subjects were given psychological tests during the collection of the first hour basal samples and were intubated during collection of the second hour basal samples Analyses falled to reveal any significant differences between Hour 1 and Hour 2 catechol output etther on Day 1 or Day 2 for etther ulcer or control subjects

The possibility of a "novelty" or "first tıme" effect in Expt 1 was examıned in two ways First, the catechul outpul of the first experimental day was compared with that of the second These analyses revealed no difference between Day 1 and Day 2 with respect to noradrenalıne excretıon but indicated a significantly greater mean adrenalıne output on the first than on the second day, both for the ulcer and control groups Secondly, the catechol output of the first hour of the first experimental day was compared with the mean of the other three basal samples Both ulcer and control subjects showed no significant difference with respect to rate of noradrenaline output but had significantly higher adrenalıne rates durıng the first than durıng the subsequent three basal periods, in addition, both groups showed lower urine volumes during the first basal perıod than during the subsequent basal periods The question to be considered is whether these indications of a "first-time" effect militate against the conclusion that ulcer subjects have lower noradrenaline excretory rates than do control subjects One fact suggests that the answer is negative, in the experiment the noradrenaline output of ulcer subjects was found to be significantly lower than that of control subjects during the last three basal periods as well as during the first

(8) Reproducibility of catechol data in experiment Spearman correlation coefficients (SIEGEL, 1956) were computed to assess the similarity of the Hour 1 and Hour 2 catechol data.

The results indicated good reproducibility in the case of noradrenaline (rho values were +070 , $+058,+069$ and +084 ) but poor reproducibility in the case of adrenalıne (rho values were -002 , $+052,-021$, and -001 ) To determine the reproducibility of the catechol data on two different days, the Hour 1 and Hour 2 data of Day 1 were summed and correlated with the summed data of Day 2 It was found that the control subjects had good reproducibility both with respect to epinephrine (rho $=+067$ ) and norepinephrine (rho $=+060$ ) but that the ulcer subjects had poor reproducibility both with respect to epinephrine $($ rho $=-+008)$ and norepinephrine (rho $=+013$ )

It is interesting that there was good reproducibility in adrenaline and noradrenaline levels on Day 1 and Day 2 (for basal specimens) in the control subjects and poor reproducibilty in the ulcer patients It may be that the ulcer subjects response to the psychological testıng durıng the first "basal" perıod on day 1 was responsıble, however no definite evidence can be presented to support this

The good reproducibility of noradrenaline levels when Hour 1 and Hour 2 are compared and the poor reproducibility of adrenalıne levels may be more of an individually determıned variable (a more consistent individual trait less influenced by external factors )

\section{Correlates of Catechol Amme Levels and Gastruc Secretion}

In the previous section the results of the various tests and measures were compared in ulcer patients and control subjects Many of the differences between the two groups were highly significant and many of the pre-experimental hypothesis and predictions were supported

The data was also considered in terms of the correlations of various measures to 
the catechol amine levels and the correlates of gastric secretory levels regardless of whether the subject was an ulcer patuent or a control subject.

Except for the predictions already stated (e g FTT and catechol amınes) the data summarized in this section was not examined to test hypothesis which were formulated prior to the experiment. Rather, the data was examined in an exploratory fashion to determine new "leads" by post hoc review and interpretation of the data.

The data is presented in summary form since it can, at best, be considered as preliminary and suggestıve.

There was another reason for examining the correlations of the various measures with the catechol amme levels and gastric secretion disregarding the ulcer/non-ulcer division. It was the feeling of the investigators that on the basis of the correlations of the measures with the presence or absence of an ulcer certain relationships with the catechols and gastric secretion would be "expected" and other relationships would not be expected If these expectations were confirmed the data would carry a greater degree of certainty and more definitive hypothesis could be constructed

(A) Noradrenaline letels The "basal" noradrenalıne levels (four basal periods combined) significantly correlated with the noradrenaline level obtained after insulin administration $(P=005)$ but there was no correlation of the "basal" noradrenaline levels with the adrenaline level after insulin induced hypoglycemia.

The "basal" noradrenaline levels, the noradrenaline levels after insulin induced hypoglycemia and the mean value of all noradrenalıne levels for each subject showed significant negative correlation with the "hyper" secretor score on the post experimental interview ("basal" levels $P=0.01$, after insulın $P=005$ and mean value of all specimens $P=0$ 05)

The "hyper" secretor scores on the psychological test battery (DAP, Saslow and Blacky) showed a negative correlation with the "basal" noradrenaline levels, level after insulin and mean value of all noradrenaline specimens However, only the correlation with the post insulin level was significant at 005 level

(B) Adrenaline lezels The "basal" adrenaline levels correlated with the adrenaline and noradrenaline levels after insulın hypoglycemı. The correlatıons were significant at the 005 level

There was no correlation between the "basal" adrenalıne level, the adrenaline level after insulın and the mean value of all adrenalıne levels with the "hyper" secretor scores on the psychological lest battery or the post expermental interview

(C) Gastric secretion As mentioned previously the mean volume and free acidity of the gastric secretion of the ulcer group was higher than that of the control group. However, there was considerable variation in each group and overlap between the groups so that there were no statistically significant differences.

The basal gastric secretion (Day 1 and 2 combined) showed a negative correlation with the combined basal noradrenaline level $(P=005)$ and the mean value of all noradrenalıne specimens $(P=005)$ There was a negative correlation with the noradrenalıne level after insulin but it was not statistically significant. ( -027$)$

The combined basal gastric secretion levels showed a negative correlation with the combined basal adrenalıne level $(-0 \cdot 24)$, adrenalıne level after insulın $(-0 \cdot 21)$ and the mean value of all adrenalıne levels $(-0.34)$ but none of the correlations were statistically significant at the 005 level.

The gastric secretory levels after insulin and the mean value of all gastric secretory 
levels showed no significant correlations with the combined basal adrenaline or noradrenalıne levels, the adrenaline or noradrenalıne values after insulin or the mean value of all adrenaline as noradrenaline levels. However, in all instances that gastric secretory levels and the noradrenaline levels had a negative correlation whereas there was considerable variation with the adrenaline levels.

The combined "basal" gastric secretory levels, the levels after insulın hypoglycemia and the mean value of all gastric secretory specimens did not significantly correlate with the scores on the FTT or the "hyper" secretor scores on the psychological test battery (DAP, Saslow and Blacky). However, the gastric secretory level after insulın and the mean value of all gastric specimens showed a positive correlation with the "hyper" secretor score on the psychological test battery that almost reached a 005 level of significance $(+037$ with +0377 being necessary for $P=0.05)$.

The "hyper" secretor score on the post experimental interview was significantly correlated with all the gastric secretory levels. ("Basal" levels $+0 \cdot 47$, after insulin +041 mean of all levels $+0 \cdot 45$ ) The correlation was significant at the 005 level in all instances.

\section{DISCUSSION}

One conclusion arising from the investigations presented in this paper is that the ulcer patients have a lower noradrenaline excretıon than do individuals without ulcers. Significant differences were found during "basal" conditions, after stimulation with peptone broth and insulin.

The psychological test battery assessed a series of psychologic "hyper" secretor and "hypo" secretor which had been described in the study by Weiner et al (1957) These psychological factors identıfied the ulcer and non ulcer patıent subjects at a statıstically significant level Furthermore, an interview conducted following the test procedures which also attempted toidentıfy "hyper" and "hypo" secretor psychologic factors in relation to the test situation, was able to identify the ulcer and control subjects at a high level of significance Perhaps, of more significance was the fact that the ratings on the post intubation interview correlated significantly with the actual gastric secretions, and was inversely correlated with noradrenalıne levels

Of further interest was the fact that the gastric secretory values did not show a significant difference in the ulcer and control groups Although the mean values were higher in the ulcer group The scores on the Focused Thematic Test correlated significantly with the total catechol amine output and the adrenalıne percent during the test period but did not correlate catechol amine levels obtained in the other test periods However, the FTT score did not discriminate the ulcer and control subjects

The physiological and biochemical data was collected for the purpose of studying whether autonomic nervous system "balance" might be conceptualized by examinıng gastric secretory actıvity and urinary catechol excretion

Although there is substantial evidence of a close correlation between the urinary excretion of catechol amine and sympathetic activily (von Euler 1956) it does not seem justifiable to assume that the low noradrenaline output of the ulcer patients is an indisputable indication of low sympathetic activity Some metabolıc difference, such as activity of deamınatıng enzyme systems or the affects of other hormones could conceivably result in lower free catechol amine excretions in the urine of ulcer patients However, pending some definite evidence of such mechanisms, the assumption that low catechol amine output in the urine of ulcer patients is indicative of low sympathetic activity seems warranted and helpful in expanding the approach to the problems of the control of gastric secretion in duodenal ulceration It is not proposed that low sympathetic activity is the only disturbance of autonomic function underlying the ulcer diathesis But rather that this is one aspect of a complex central nervous system dysfunction probably involving the hypothalamus and associated reflex centers

This paper furthermore does not propose to delineate whether the psychodynamic, developmental and interpersonal factors are primarily responsible for the autonomic 
inhibition or dysfunction which the data suggests. Furthermore, there is no evidence to suggest that the psychodynamic factors are the result of the autonomic dysfunction or other metabolic dysfunctions which may lead to the development or enhancement of "oral" needs or the reinforcement of conflicts in the oral area All that can be defin1tively stated is that the data suggests that a relationship does exist between specific psychodynamic patterns and specific autonomic response characteristics (as reflected in a catechol amine levels )

The results did strongly suggest that duodenal ulcer formation is related to low noradrenaline excretion In addition, gastric secretion and acidity (at least durıng the "basal" periods) were inversely related to the noradrenaline excretion These findings support the hypothesis of Waddell and others that gastric secretion is, in part, a function of gastric blood flow and to some extent may be controlled by the rate of transfer of water and ions from the blood vessels to the gastric lumen This is further supported by evidence shown by WADDELL (1958) that gastric secretion can be arrested by the intravenous infusion of noradrenalıne. Gastric blood flow appears to be an important factor in the etıology of duodenal ulcer yet there is a paucity of data on this topic

The effect of removal of the pylonc antrum as a source of afferent impulses in reducing gastric secretion was briefly referred to in the introduction. Work by WADDELL has been undertaken to determine the possible role of the antrum in the control of gastric blood flow It was demonstrated that antrectomy resulted in vasoconstriction of some of the gastric vessels The antrum seems to function as a site of origin of visceral afferent impulses which influence the central reflex centers and the tonic discharges to the autonomic nervous system.

The multiple factors responsible for the basal secretion of the resting stomach have not been accurately defined However, it has been shown that vagal integrity is important There is general agreement that nervous influences account for a large part of the secretory activity of the empty stomach WADDELL has described an unmistakable influence that the removal of the antrum has a pronounced affect upon basal secretion

Although there is no certain proof, the observed changes in basal secretion produced by antrum excision seem consistent with the concept that the antium is a source of afferent impulses which pass to central reflex centers and exert an effect upon the tonic state of such centers and the efferent discharge over parasympathetic pathways

If non-ulcer subjects differ from ulcer subjects in the sensitivity of the antrum then one would expect that basal secretions and the secretion after peptone broth would differ from that of ulcer subjects as the non-antrectomized differed from those with their antrums removed Since this evidence was not present in this study, sensitivity of the antrum did not appear to be the major difference which would account for susceptibility of one group to develop ulcers

Histamıne presumably exerts its affect directly upon the parıtal cell of the stomach Its stimulating action upon the output of acid in the stomach is potentiated by parasympathomimetic drugs Most observers have found the secretory response to hisamine greatly reduced after vagatomy WADDELL observed that antrum excision reduces or abolishes the ability of the gastric remnant to respond to histamine The non-ulcer patients in this particular study did respond to histamine with secretion The results of histamıne stımulation again does not support antral sensitivity as the primary difference in the ulcer-non-ulcer group

It would appear that the gastric secretion which occurs following insulin hypoglycemia is a result mainly of stimulation of the vagal centers of the brain, probably the hypothalamus The effects of the stimulation of the hypothalamus are carried to the stomach over the parasympathetic pathways principally the vagus Atropine, for example lessens or abolıshes insulin stımulation The avarlable evidence indicates that cholinergic discharges from excitation of centrally placed para-sympathetic reflex centers are responsible for the gastric secretory effects of insulın 
The evidence from this experiment suggests that the main difference in the two groups, ulcer and non-ulcer, is a function of variations in tonic influences exerted on the reflex centers by the hypothalamus. It is interesting that the stimulus which primarily affects the effector side of the reflex (histamıne) produced similar catechol amine and gastric secretory responses in both groups of subjects. While stimulı affectıng the afferent side of the reflex (peptone broth)* or stimuli which involved the hypothalamus (insulın) highlighted the differences between the two groups Actually the conclusions being drawn here are based on the fact that the difference in noradrenalıne levels was possibly reflectıng different levels of perıpheral sympathetic activity.

It is hypothesized that the neurophysiologic difference between the two groups is not at the mucosal afferents, the neuro-effector or medullary levels, but probably at the hypothalamic level The difference may involve a variation in the tonic inhibitory tone exerted by the hypothalamus on the medullary gastro-intestinal centres Hence, if one stimulated the medullary reflex centers there might be no difference in sympathetic or parasympathetic reflexes in the two groups. This was suggested by the fact that the histamine produced a noradrenalıne response which was equal in both groups. Insulin however, produced a considerably greater noradrenaline response in the nonulcer group. (It is assumed that insulin is affecting primarily the hypothalamus while the central action of histamine has been described as stımulating medullary reflex areas )

The hypoglycemia induced by the insulın is believed to lead to stimulation of posterior hypothalamus which further leads to peripheral sympathetic discharge as well as the activation of an adrenal medullary discharge The fact that there was no great difference in the adrenaline levels but only a difference in the noradrenaline levels suggests the adrenal medulla and/or the sympathetic innervation of the adrenal medulla is not deficient or dysfunctioning. The evidence points to a dysfunction under certain conditions of the sympathetic fibres concerned directly with the activity or blood supply of the stomach.

The data from this experiment suggests that the concepts which were formulated by WeINER, REISER, THALER, and MIRSKy (1957) can be supplemented by the following information. The catechol amines are believed to be a reflection of the activity of the sympathetic nervous system as well as the adrenal medulla. Gastro-intestınal motor and secretory activity may be a result of neurogenic influences which includes a system of afferent fibers from the antral mucosa which go to the medullary reflex centers and the hypothalamus. The hypothalamus in turn may exert an inhibitory or facilitatory influence on the medullary reflexes. A decrease in the hypothalamic inhibition of medullary reflexes will lead to an increase in gastro intestinal reflexes and hence an increase in gastro-intestinal activity Psychologic influences may affect the hypothalamus and alter its inhibitory or facilatory tone. On the other hand it may be that individuals who have a dysfunction of the hypothalamus not only display certain physiological differences in terms of gastric functioning but also display certain emotional and motoric behavioral differences. It may be that these differences are all contributed to by the central hypothalamic dysfunction (1 e. an hypothalamic imbalance may lead to the autonomic, physiologic, endocrinologic, behavioral, affective and psychodynamic correlates noted in patients with peptic ulcer.

\footnotetext{
* Stimulation of gastric secretion by peptone broth is not felt to be purely reflex, e g some feel peptone stimulates release of gastrin
} 
ENGEL (1958) pointed out that in the infant with a gastric fistula outgoing affects and increased motor activity were associated with the highest gastric secretory rates It is interesting that in adults, actıve or overt expressions of aggression do not seem to be characteristic of individuals who develop duodenal ulcers These findings are not contradictory In a child one would expect a much more diffuse discharge from hypothalamic centers during states of activity which would include sympathetic and parasympathetıc fibers In adults aggressive motor behavior which was discharged to muscular channels might not be associated with gastro intestinal activity The work of GASTAUT (1958) suggests that when cortical component of a conditioned response has been blocked either by drugs or by decortication then diffuse affective and autonomic components of conditioned response may predominate Obviously part of a cortical response might be a motoric act GASTAUT has pointed out that the caudal projections of the reticular system are inhibited when the rostral projections are activated Hence, autonomic and affective responses associated with conditioning are inhibited when cortical motor responses are facillitated If there is no performance of an aggressive act then the autonomic and affective components may be most prominant The inhibition of motor conditioned reflexes or the voluntary learning of suppression of aggressive hebavioi may show in humans as it does in cats, high amplitude, slow rhythms, in the unconditioned area during the process of inhibition Further work in this area might be benefitted by the utilization of conditioning techniques in which gastric secretory responses were studied in conjunction with conditıoned aggressive opperant behavior

It is necessary to interpret the results of this project cautiously. Although certain relationships are strongly suggested by the data, there are many discrepancies and exceptions to even the statistically significant results. If a proper understanding of the psychophysiology of gastric secretions is to be developed these discrepancies must ultimately be explained. Perhaps the major area for caution involves the techniques and methods and the interpretations of the results. It must be recognized that even with the improvements in laboratory techniques, measurement errors are still considerable. The measurement of urinary catechol amines as an index of sympathetico adrenal responsivity is of course still open to many questions. In fact the whole significance of the urinary levels is far from clear Although the particular assay method utılized in this study appears to be an accurate method of determining the presence of catechol ammes in the specimen, the use of urunary specimens leaves many questions to be answered, among them the origin of catechol amines which are present in the urine Furthermore, the levels noted cannot necessarily be taken to reflect the overall amount of catechol amines released in the body during a period of time. Even if most of the adrenalıne and noradrenaline noted in the urine results from adrenal medullary and sympathetıc nervous system activity, the effects of differences in adrenal clearance rates or differences in the metabolism of the catechol amines in different persons is still not clearly delineated It would be of particular importance in establıshing the mechanısm involved in a psychophysiological chain of events to have avalable an accurate, rapid and sensitive measure which could detect changes in several parameters which are under investigation. If simultaneous measures of the changes in several parameters could be performed then the question of causality might be further clarified Naturally a measure of urinary catechol amine levels representing the excretion over a one-hour period is far from ideal.

The utilization of catechol amıne levels as an index of sympathetıc nervous system activity or adrenal medullary responsivity merely compounds the problems already introduced by the questions raised by technique, questions raised about metabolism and questions about adrenal clearance of the catechols

Furthermore, one must be extremely conservative in the theoretical assumptions 
drawn from the data since the methods of evaluation of the psychologic factors are subject to many technical areas due to the inaccuracy of the techniques, as well as, the biases introduced by the experimenters. The utilization of definite criteria which were established prior to the reduction of the data, the complete independence of the functionng of the two teams of investigators certainly contributed to the significance of the findings But it does little in helpıng us to understand the mechanisms and processes underlyıng the relatıonshıp of gastric secretory activity, catechol amın excretion and psychologic factors

There were several obvious omissions in this study which leave several questions unanswered For example, the inability to carry out measures of gastric motılity was unfortunate It is well recognized that the introduction of a new measure often introduces new variables into an experiment Nevertheless recent developments have shown promise that new experimental tools may be forthcoming which may be admirably suited for studies such as the one described in this particular paper In addition, the fallure to measure pepsin secretion in the stomach or urinary or serum pepsinogen levels did not permit direct comparisons with the work of previous investigators, some of whose techinques and criteria were utilized in this study

Although an attempt was made to structure the interviews in the psychological tests so that specific psychodynamic information could be obtained and reliable correlations between psychodynamic areas, catechol amınes and gastric secretıons carried out, the techniques avaılable for the assessment of the behavioral and emotional information was far from satisfactory Future approaches utılizing specific perceptual cures at limınal and sublımınal levels together with classical and operant conditioning techniques may lend themselves amiably to more sophisticated studies allowing for a better delıneation of the relationship of behavioral and emotional processes, to physiological activitıes and endocrinologic functions

Many of the areas discussed in this paper may not appear related to psychiatric problems or even germane to psychosomatic areas However, an effort has been made to relate only those findings pertinent to broddenıng the understanding of the psychophysiological influences on gastric functionıng

In spite of the voluminous literature on duodenal ulcer the pathophysiology is still not well defined and the mechanics of gastric physiological responses to emotional processes is even more vague

This study does not attempt to do more than introduce another dimension which should be considered in understanding the translation of psychic processes into somatic changes As our information regarding the complex pliysiological, endocrinological and neurophysiological interactions involved in gastric functionıng expands, we can expect our abilities to more meaningfully and specifically utilize psychological techniques to assist our surgical and medical colleagues in the treatment of duodenal ulcer to improve

\section{SUMMARY}

Gastric secretory studies and urinary assays for catechol amınes were carried out on 10 patients with radiologically proven ulcers and 10 non-ulcer patients. A group of psychological tests and a specially constructed interview were administered The patients whose psychological measures were scored (without any knowledge of clinical diagnosis, gastric secretion and urinary catechol amine levels) as demonstrating a high degree of anxiety and a low level of, or a discomfort with the expression of aggressive impulses were noted as being most likely to have a low noradrenaline output, and a duodenal ulcer

The psychological measures discriminated ulcer and non-ulcer patients at a 001 level of confidence Nor-adrenaline levels were lower in ulcer than non-ulcer patients.

The results reconfirmed the correlations previously noted in three types of studies (1) The levels of adrenalıne and noradrenalıne excreted in a patient's urine correlates with the degree of aggressivity and anxiety expressed on specific psychological test measures, (2) Specific psychological characteristics can discriminate ulcer and 
non-ulcer patients, (3) The ratio and level of urinary catechol amines may be a reflection of autononinc minbalance and are associated with duodenal ulcers.

\section{REFERENCES}

ALEXANDer $F$ et al (1934) The influence of psychologic factors upon gastrointestinal disturbances Psychoanal Quart 3, 501

Babkin B P and Schacter M (1950) Cited in Secretory Mechanism of the Digestive Glands, 2nd edition, New York, Hoever

BARD P (1949) Central nervous system mechanism for the expression of anger in animals In Feelıngs and Emotions (Edıt ReYMeR M L) McGraw-Hıll, N Y

BLum G S (1951) Revised scoring system for research use of the Blacky pictures (Male form-1951) Ann Arbor, Mich, Untv of Mich

Chapman W, Livingston R, Livingston K and Sweet W (1950) Possible cortical areas involved in arterial hypertension Proc Ass Res Nerv Dis, 29, 775-798

Cohen S I and Silverman A J (1959) Psychophysiological investigations of vascular response variability $J$ Psychosom Res 3, 185-210

Dragstedt L R, Woodward E R, Storer E H, Oberhelman H A and Smith C A (1950) Quantitative studies on the mechanısm of gastric secretion in Health and disease Ann Surg, 132, 626

Du Tort C H (1959) A study of chemical methods for quantitative measurements of catechol amines. Wright Air Development Center Technical Report 59-175, Wright-Patterson Aır Force Base, Ohı

ENGel G, ReuHSMan F and Segal H (1958) A study of an infant with a gastric fistula Chapter in Psychopathology Source Book edited by READ, Alexander and Sarnhms, Howard University Press

voN Euler, U S. (1956) Noradrenalne Philadelphra, Chatles C Thomas \& Company, Chap $\mathrm{X}, \mathrm{XI}, \mathrm{XII}$

FolKow B and vON EuLer U S (1954) Selective activation of noradrenaline and adrenaline producing cells in the cat's adrenal gland by hypothalamic stımulation Corc Res , 2, 3

GASTAUT H (1958) Some aspects of the Neurophysiological basıs of conditioned reflexes and behavior Chapter in Ciba Foundation, Symposium on the Neurological Basis of Behavior, edited by WOLSTENHOLME G E and O'ConNor C M. Boston, Little, Brown and Company

GellHORN E (1956) Analysis of autonomic hypothalamic functions in the intact organism Neurology 6,335

Gellhorn E , Nakao H , RedGate E S (1956) The influence of lesions in the anterior and posterior hypothalamus on tonic and phasic autonomic reactions $J$ Physiol 131, 402

GellHORN E and REDGate E S Hypotensive drugs (acetylcholine, mecholyl, histamıne) as indicators of hypothalamic excitability of the intact organism Arch int Pharmacodyn 102, 162, 1955

GILDEA E G (1949) Special features of the personality which are common to certain psychosomatic disorders Psychosom Med, 11, 273

Glass G B J and Wolf S. (1960) Hormonal mechanisms in nervous mechanism of gastric acid secretion in humans Proc Soc exp Biol Med 73, 535

Grossman M I (1951) "A Critical Analysis of Varıous Theories of the Pathogenesis of Peptic Ulcer" In Sandweiss, D J Peptic Ulcer Phıladelphia, Saunders

Hess W R (1949) Die funktionelle organization les vegetativen nervens systems Schwable, Basal.

HILLARP N S (1953) Evidence of adrenalıne/noradrenalıne in separate adrenalıne medullary cells Acta physiol Scand 30, 55-68

HUNT J N and KAY A W (1954) The nature of gastric hypersecretion of acid in patients with duodenal ulcer Brit Med $J$ 2, 1444

Ivy A C, Grossman M I and Bachrach W H (1950) Peptic Ulcer New York Blakıston

Kapp F T , Rosenbaum M and Romano J (1947) Psychological factors in men with peptic ulcers Amer $J$ Psychiat, 103, 700

LEONSINS A $J$ and WADDELL W R (1958) The inhibitıng effect of norepinephrine on gastric secretions in human subjects $J$ appl Physiol 12, 334

MINSKI L and DESAI M M (1955) Aspects of personality in peptic ulcer patients Brit $J$ med Psychol, 28, 113

Mirsky, I Arthur (1958) Physiologic psychologic and social determinants in the etiology of duodenal ulcer Amer $J$ Digestive Diseases 3, 285-314 
Ruesch J (1948) The infantile personality Psychosom Med 10, 134

WADDELL W R (1956) The physiologic significance of retained antral tissue after partial gastrectomy Ann Surgery, 143, 520-553

Waddell W $R$ and Williams $H$ W, JR The effect of antrectomy on Gastric Blood Flow (In preparation)

WAdDELl W and Zuidema G A (1960) Urinary catechol amine excretion in duodenal ulcer patients $J$ Clin Invest (In Press)

Weiner H, Thaler M, Reiser M F and Mirsky, I Arthur (1957) Etrology of duodenal ulcer Psychosom Med, 19, 1-10, No 1

Weisman A D (1956) A study of the psychodynamics of duodenal ulcer exacerbations Psychosom Med 18, 2

WiLSON D W and BALL E G (1928) Study of estımation of chloride in blood and serum $J$ brol Chem 79, 221

Saslow G, Counts R M and Dubois P H (1951) Evaluation of a new psychiatric screenıng test. Psychosom Med 13, 242

SiEGEL S (1956) Nonparametric Statistıcs for the Behavioral Sciences New York, McGraw-Hill Book Company, p 202

Sirverman A J, Cohen S I, Zuidema G and Lazar C (1957) Prediction of physiologic stress tolerance by projective tests The Focused Projective Test $J$ prof Tech 21, 2

Streitfeld H S (1954) Specificity of peptic ulcer to intense oral conflicts Psychosom Med 16, 315 Szasz T S et al (1947) The role of hostility in the pathogenesis of peptic ulcer Psychosom Med 9, 331 . 